\title{
PENGARUH PEMBERIAN PAKAN AZOLLA MICROPHYLLA TERHADAP PERTUMBUHAN IKAN NILA (OREOCHROMIS NILOTICUS) SEBAGAI RANCANGAN PEMBELAJARAN BIOLOGI SMA
}

\author{
Suwondo ${ }^{1)}$, Darmadi ${ }^{2)}$, Muhammad Amin ${ }^{3)}$ \\ E-mail: muhammad.amin0444@student.unri.ac.id \\ 1) 2) ${ }^{3)}$ Pendidikan Biologi, FKIP Universitas Riau
}

\begin{abstract}
This study aims to determine the growth of tilapia (Oreochromis niloticus) with the use of Azolla microphylla feed and its potential to produce a module design on the material for growth and development of living things in class XII odd semester KD 3.10 and KD 4.10. This research was conducted from May to August 2020 at Selais's Lake LPPM Riau University. This study used 2 stages, namely. Phase I research used quantitative descriptive to determine the growth of tilapia on Azolla microphyla feed with different feeding percentages. Fish were grouped into 3 treatments and 1 control. Fish are reared in different cages with different percentage of feeding. The research parameters included absolute length growth, absolute weight growth, nisbi growth rate, and survival rate. Phase II research is a module teaching material design that uses 2 stages, namely, the Analyze and Design stages. The results of the experimental stage of research, feeding Azolla microphylla affected the growth of tilapia (Oreochromis niloticus). P3 treatment (giving 5\% Azolla microphylla from fish biomass) is the best dose in increasing the growth of tilapia. Resulted in the absolute length growth of $4.24 \mathrm{~cm}$, absolute weight $11.72 \mathrm{~g}, 4.68 \%$ relative growth, $4,68 \%$ specific growth rate and $99.4 \%$ survival rate. The P3 treatment resulted in a growth which was much lower than the P0 treatment.
\end{abstract}

Keywords : Growth of tilapia (Oreochromis niloticus), Azolla microphylla, Design of learning modules

\section{PENDAHULUAN}

Perairan tawar (fresh water) di Indonesia memiliki potensi yang sangat besar untuk dimanfaatkan sebagai lahan budidaya ikan air tawar. Jenis-jenis yang sudah umum dibudidayakan oleh masyarakat antara lain ikan nila, mas, lele, gurami, tawes, bawal (KKP, 2018). Ikan nila merupakan jenis ikan yang banyak diminati oleh konsumen ikan air tawar. Usaha budidaya ikan nila sangat berkembang pesat di Indonesia. Menurut Arif (2019) Ikan nila memakan makanan alami berupa plankton, perifiton dan tumbuhtumbuhan lunak seperti hydrilla, ganggang sutera dan klekap. Pada masa pemeliharaan, ikan nila dapat diberi pakan buatan (pellet) yang mengandung protein antara 20-25\%.

Azolla microphylla merupakan tumbuhan paku air yang dapat tumbuh dan berkembang dengan cepat, serta bersimbiosis dengan Cyanobacteria yang mampu memfiksasi nitrogen di udara. Dengan kemampuannya bersimbiosis ini dapat menyebabkan biomassa Azolla microphylla mempunyai kualitas nutrisi yang baik khususnya nitrogen dan senyawa bentukannya seperti protein. Selain itu, tingkat pertumbuhan Azolla microphylla juga sangat cepat, yaitu dapat menggandakan diri dalam 
kisaran waktu 2-10 hari tergantung kondisi lingkungan dan ketersediaan nutrisi (S.B Katole et al., 2017).

Modul merupakan sebuah bahan ajar yang disusun secara sistematis dengan menggunakan bahasa yang mudah dipahami oleh peserta didik serta dapat dipelajari secara mandiri (Yaki et al., 2020). Modul memiliki kelebihan membuat siswa bisa belajar mandiri dengan atau tanpa seorang fasilitator sehingga siswa bisa membuat pengalamanya sendiri untuk memahami suatu permasalahan atau materi. Modul juga memiliki salah satu karakteristik yang disebut dengan stand alone, artinya modul tidak tergantung pada media lain atau tidak harus digunakan bersama-sama dengan media lain (Prastowo, 2015).

Materi pertumbuhan telah dijadikan sebagai konsep materi biologi dan dipelajari dijenjang SMA kelas XII semester ganjil pada KD 3.1. Berdasarkan hasil observasi dan pengalaman penulis ketika melaksanakan kegiatan PLP (Pengenalan Lapangan Persekolahan) melihat kurangnya inovasi bahan ajar oleh guru dan kebanyakan guru hanya menggunakan buku paket. Konteks materi hanya secara makro dan tidak dilengkapi dengan contoh faktual yang berada disekitar lingkungan peserta didik, kurang variatif dan tidak kontekstual. Hal ini tentu tidak sesuai dengan Kurikulum 2013 yang menuntut guru untuk bersikap kreatif dan inovatif dalam mengembangkan dan menyiapkan bahan ajar. Salah satu bahan ajar yang dapat diperkaya isinya adalah modul sehingga siswa bisa mempelajari suatu materi secara kontekstual. Menurut Dita (2014), efektifitas modul dalam upaya meningkatkan hasil belajar kognitif siswa SMA sangat signifikan serta menjadikan siswa lebih mandiri dalam proses pembelajaran.

\section{METODE PENELITIAN}

Penelitian ini merupakan penelitian deskriptif kuantitatif. Penelitian ini menggunakan deskriptif kuantitatif untuk mengetahui pertumbuhan ikan nila terhadap pakan Azolla microphyla dengan persentase pemberian pakan yang berbeda. Ikan dikelompokkan menjadi 3 perlakuan dan 1 kontrol. Ikan dipelihara dalam keramba yang berbeda dengan persentase pemberian pakan yang berbeda.

Keramba 1: pakan merk Matahari Sakti PF 800 (Kontrol)

Keramba 2: pakan Azolla 3\% dari bobot biomassa ikan (Perlakuan 1)

Keramba 3: pakan Azolla 4\% dari bobot biomassa ikan (Perlakuan 2)

Keramba 4: pakan Azolla 5\% dari bobot biomassa ikan (Perlakuan 3)

Penelitian ini dilaksanakan di Danau Selais LPPM Universitas Riau pada bulan Mei sampai dengan Agustus tahun 2020. Peralatan yang digunakan dalam penelitian ini yaitu alat-alat tulis, DO meter, termometer, pH meter, kamera, neraca analitik, keramba, baskom, dan tangguk ikan. Adapun bahan yang digunakan yaitu pakan komersil merk Matahari sakti, pupuk kandang, Azolla microphyla dan ikan nila (Oreochromis niloticus). Pengambilan sampel ikan uji dan bahan pakan uji dilakukan dengan metode purposive sampling. Prosedur penelitian terdiri dari persiapan keramba penelitian, pembibitan pakan Azolla microphylla, dan pemeliharaan ikan uji. Data hasil penelitian dianalisis secara deskriptif kuantitatif. Data hasil pengamatan pertumbuhan bobot mutlak, laju pertumbuhan spesifik, dan kelulushidupan. Tahap perancangan modul dari hasil penelitian menggunakan 2 tahap yaitu tahap analyze dan design. Tahap analisis yang dilakukan adalah analisis kurikulum, analisis hasil penelitian dan analisis silabus kemudian menentukan kompetensi dasar (KD). Tahap perancangan dilakukan dengan menentukan materi pokok, menentukan indikator pencapaian kompetensi (IPK). Setelah itu merekonstruksi silabus yang telah dikeluarkan kemendikbud 2019, merancang RPP sesuai dengan tuntutan kurikulum 2013 dengan pendekatan saintifik menggunakan model PBL. 


\section{HASIL DAN PEMBAHASAN}

\section{Pertumbuhan Bobot Mutlak}

Pertambahan bobot ikan nila meningkat seiring dengan bertambahnya waktu pemeliharaan. Pertambahan bobot ikan nila pada masing-masing perlakuan setiap minggunya selama 12 minggu pemeliharaan dapat dilihat pada Gambar 1.



Gambar 1. Pertambahan Bobot Rata-rata Ikan Nila

Pada Gambar 1 dapat dilihat minggu ke0 (setelah aklimatisasi) sampai minggu ke-12 pemeliharaan. sudah mulai terlihat hasil yang berbeda-beda pada masing-masing perlakuan. Hasil pengukuran pertumbuhan bobot mutlak ikan nila disajikan pada Tabel 1 .

Tabel 1. Pertumbuhan Bobot Mutlak Ikan Nila (Oreochromis niloticus)

\begin{tabular}{|c|c|c|}
\hline \multirow[b]{2}{*}{ Perlakuan } & \multicolumn{2}{|l|}{ Parametere } \\
\hline & $\begin{array}{l}\text { Pertumbuhan } \\
\text { Mutlak (g) }\end{array}$ & Bobot \\
\hline P0 (Pelet 3\%) & 19,69 & \\
\hline $\begin{array}{l}\text { P1 (Azolla } \\
\text { microphylla 3\%) }\end{array}$ & 9,48 & \\
\hline $\begin{array}{l}\text { P2 (Azolla } \\
\text { microphylla 4\%) }\end{array}$ & 10,56 & \\
\hline $\begin{array}{l}\mathrm{P} 3 \text { (Azolla } \\
\text { microphylla 5\%) }\end{array}$ & 11,72 & \\
\hline
\end{tabular}

Berdasarkan Tabel 1 menunjukkan pemberian pakan Azolla microphylla terhadap pertumbuhan bobot mutlak ikan. Pada perlakuan pelet 3\% dari bobot biomassa ikan menghasilkan pertumbuhan bobot mutlak sebesar 19,69 g, perlakuan Azolla microphylla $3 \%$ dari bobot biomassa ikan menghasilkan pertumbuhan bobot mutlak 9,48 g, perlakuan Azolla microphylla 4\% dari bobot biomassa ikan menghasilkan pertumbuhan bobot mutlak 10,56 g, dan perlakuan Azolla microphylla $5 \%$ dari bobot biomassa ikan menghasilkan pertumbuhan bobot mutlak 11,72 g. Pertumbuhan bobot mutlak tertinggi ditunjukkan pada perlakuan pelet 3\% dari bobot biomassa ikan sedangkan pertumbuhan bobot mutlak yang paling rendah terdapat pada perlakuan Azolla microphylla 3\% dari bobot biomassa ikan. Perlakuan Azolla mirophylla $5 \%$ dari bobot biomassa ikan menunjukkan pertumbuhan bobot mutlak tertinggi dibandingkan Azolla microphylla 3\% dan 5\% dari bobot biomassa ikan.

Pertumbuhan bobot mutlak pada perlakuan Azolla microphylla 5\% dari bobot biomassa ikan lebih tinggi dibandingkan perlakuan Azolla microphylla 3\% dan 4\% dari bobot biomassa ikan. Hal ini berarti pemberian pakan Azolla microphylla dengan persentase yang berbeda dapat memengaruhi tingginya pertumbuhan bobot mutlak pada ikan nila. Pertumbuhan bobot mutlak terbaik dengan pemberian pakan Azolla microphylla terdapat pada perlakuan Azolla microphylla 5\% dari bobot biomassa ikan dikarenakan pada perlakuan tersebut memiliki persentase pemberian pakan lebih besar dibandingkan perlakuan perlakuan Azolla microphylla lainnya.

Pada perlakuan pelet 3\% dari bobot biomassa ikan memiliki selisih pertumbuhan bobot mutlak yang tinggi dibandingkan perlakuan Azolla microphylla. Tingginya pertumbuhan bobot mutlak pada perlakuan pelet 3\% dari bobot biomassa ikan dikarenakan perlakuan tersebut dapat memenuhi kebutuhan sumber nutrisi ikan nila untuk pemeliharaan dan pertambahan bobot ikan. Menurut Eka (2020), laju pertumbuhan suatu organisme ditentukan oleh kebutuhan pakan dan jenis pakan yang dikonsumsi harus cocok dengan kebiasaan makan, apabila tidak 
cocok maka organisme tersebut tidak dapat memanfaatkan pakan yang diberikan dengan baik akibatnya pertumbuhan akan terhambat atau relatif rendah.

Selisih tinggi bobot pertumbuhan mutlak antara perlakuan Azolla microphylla dibandingkan pelet 3\% dari bobot biomassa ikan disebabkan oleh tingginya kandungan serat kasar pada pakan Azolla microphylla. Menurut Noferdiman (2017), kandungan serat kasar yang tinggi pada Azolla microphylla sekitar 23,16\% dengan kandungan lignin $<15 \%$ dan selulosa berkisar $14,08 \%$. Menurut S.K Hundare (2018), kecernaan serat kasar pada pakan ikan nila tidak lebih dari $8 \%$. Kandungan serat kasar yang tinggi dapat menurunkan kecernaan nutrisi, salah satunya protein. Kecernaan protein yang rendah dapat menyebabkan rendahnya ketersediaan asamasam amino yang dibutuhkan untuk pembentukan daging. Selain kandungan serat kasar yang mempengaruhi, protein juga berperan terhadap pertumbuhan yang digunakan sebagai energi utama yang dimanfaatkan ikan. Menurut Yustiati (2018), kebutuhan protein ikan nila yaitu mencapai 49,60\%. Sehingga perlu adanya peningkatan protein dalam nutrisi pakan ikan yang diberikan untuk memenuhi kebutuhan nutrisi ikan nila.

Menurut Melita (2018), serat kasar akan berpengaruh terhadap nilai kecernaan protein. Serat kasar yang tinggi menyebabkan porsi ekskreta lebih besar, sehingga menyebabkan semakin berkurangnya masukan protein yang dapat dicerna. Pakan yang berasal dari bahan nabati biasanya lebih sedikit dicerna dibandingkan dengan bahan hewani. Hal ini dikarenakan bahan nabati memiliki serat kasar yang sulit dicerna dan mempunyai dinding sel kuat yang sulit dipecahkan.

\section{Laju Pertumbuhan Nisbi}

Pertambahan bobot ikan nila meningkat seiring dengan bertambahnya waktu pemeliharaan. Adanya peningkatan bobot ikan nila menunjukkan pertumbuhan pada ikan nila. Berikut disajikan hasil pengukuran pertumbuhan nisbi ikan nila pada Tabel 2.
Tabel 2 Pertumbuhan Nisbi Ikan Nila (Oreochromis niloticus)

\begin{tabular}{|c|c|}
\hline \multirow{2}{*}{ Perlakuan } & $\begin{array}{l}\text { Para } \\
\text { meter }\end{array}$ \\
\hline & $\begin{array}{l}\text { Laju Pertumbuhan } \\
\text { Nisbi (\%) }\end{array}$ \\
\hline P0 (Pelet 3\%) & 7,35 \\
\hline $\begin{array}{l}\text { P1 (Azolla } \\
\text { microphylla 3\%) }\end{array}$ & 3,54 \\
\hline $\begin{array}{l}\text { P2 (Azolla } \\
\text { microphylla 4\%) }\end{array}$ & 4,02 \\
\hline $\begin{array}{l}\text { P3 (Azolla } \\
\text { microphylla 5\%) }\end{array}$ & 4,68 \\
\hline
\end{tabular}

Berdasarkan Tabel 2 menunjukkan laju pertumbuhan nisbi ikan nila yang diperlihara selama penelitian berkisar antara 3,54-7,35\% dengan laju pertumbuhan nisbi tertinggi pada perlakuan pelet $3 \%$ dari bobot biomassa ikan dan yang paling rendah terdapat pada perlakuan Azolla mcirophylla 3\% dari bobot biomassa ikan. Adapun perlakuan Azolla microphylla 5\% dari bobot biomassa ikan menunjukkan pertumbuhan nisbi tertinggi dari keseluruhan perlakuan Azolla microphylla.

Penelitian ini menunjukkan pertumbuhan nisbi yang masih rendah pada perlakuan pemberian pakan Azolla mirophylla dibandingkan pelet. Hal ini dikarenakan kandungan serat kasar yang tinggi sehingga kecernaan ikan nila menjadi rendah serta berdampak pada pertumbuhan harian ikan nila menjadi rendah. Menurut Akito et al., (2017). Ikan nila memiliki daya cerna serat kasar yang rendah pemberian pakan yang tinggi akan kandungan serat kasar membuat ikan nila tidak bisa mencerna secara optimal pakan yang diberikan sehingga nutrisi yang terkandung di dalam pakan seperti protein dan lemak tidak dapat terserap dengan baik sehingga berdampak pada pertumbuhan harian ikan menjadi rendah. Menurut Arnauld S.M (2016), secara anatomi ikan nila merupakan spesies ikan yang memiliki lambung, perbedaan daya cerna terhadap serat kasar juga dipengaruhi oleh mikroflora kemampuan ikan dalam mencerna serat kasar 
dibatasi oleh kemampuan mikroflora dalam ususnya untuk mensekresikan selulosa. Pada ikan berlambung memiliki mikroflora didalam usus yang lebih sedikit dibandingkan dengan ikan yang tidak berlambung yang menyebabkan daya cerna akan kandungan serat kasar makanan tidak optimal.

Kandungan serat kasar yang tinggi berdampak pada kandunga protein yang dicerna oleh ikan nila. Jika kandungan protein yang dicerna kurang dari 20\%, dapat menyebabkan pertumbuhan ikan lebih lambat, Menurut Fatkhummubin (2019), ikan nila dapat tumbuh lebih cepat hanya dengan pakan yang mengandung protein sebanyak $20-25 \%$, pemberian pakan dengan nilai protein yang kurang dari $20 \%$ menyebabkan pembentukan jaringan baru tidak banyak terbentuk, karena tidak sesuai dengan jumlah kebutuhan ikan nila (20-25\%). Marzuki et al. (2012), menyebutkan bahwa penggunaan pakan dengan kandungan protein yang sesuai kebutuhan dan jumlah optimum akan menyebabkan pembentukan jaringan baru sehingga laju pertumbuhan meningkat. Hal ini didukung pernyataan Heptarina (2015) yang membuktikan bahwa ketersediaan asam amino pakan untuk disimpan menjadi asam amino tubuh atau protein tubuh semakin besar dengan penambahan protein dalam pakan.

\section{Tingkat Kelulushidupan}

Tingkat kelulushidupan merupakan persentase kesintasan atau ikan yang hidup berbanding ikan yang mati selama 12 minggu penelitian Data hasil perhitungan tingkat kelulushidupan ikan nila dapat dilihat pada tabel

Tabel 3. Tingkat Kelulushidupan Ikan Nila

\begin{tabular}{ll}
\hline & Parameter \\
\cline { 2 - 2 } Perlakuan & $\begin{array}{l}\text { Tingkat } \\
\text { Kelulushidupan } \\
(\%)\end{array}$ \\
\hline P0 (Pellet 3\%) & 99,65 \\
P1 (Azolla & 98,5 \\
microphylla 3\%) & \\
P2 (Azolla & 99,2 \\
microphylla 4\%) & \\
P3 (Azolla & \\
microphylla 5\%) & 99,4 \\
\hline
\end{tabular}

(Oreochromis niloticus).

Berdasarkan Tabel 3 tingkat kelulushidupan ikan nila pada semua perlakuan yaitu hampir mencapai angka 100\%. Tingginya tingkat kelulushidupan ikan pada perlakuan kontrol dan perlakuan pemberian pakan Azolla microphylla menunjukkan bahwa pakan Azolla microphylla dapat diterima dengan baik oleh ikan nila untuk menjaga kelangsungan hidupnya dan tidak menimbulkan dampak yang negatif yaitu kematian ikan nila dalam skala besar.

Menurut Sitorus (2019), selama pemeliharaan yang mempengaruhi tingkat kelulushidupan ikan nila, yaitu faktor biotik meliputi kualitas air, pakan, persaingan/kompetitor, penanganan manusia dan kepadatan penebaran serta faktor abiotik yang meliputi sifat fisika dan kimia dalam perairan. Pada penelitian ini menunjukkan bahwa wadah pemeliharaan dan kualitas air yang digunakan sesuai dengan lingkungan hidup ikan nila karena wadah pemeliharaan berupa keramba jaring apung di danau Selais LPPM Universitas Riau yang memiliki volume air cukup besar dan dapat menampung air dengan jumlah yang cukup untuk mendukung pergerakan ikan, selain itu kualitas air yang baik karena lokasi pemeliharaan ikan nila sudah sesuai dengan lingkungan pemeliharaan ikan nila skala budidaya. Wadah pemeliharaan dan kualitas air yang baik tentunya mempengaruhi nafsu ikan untuk memakan pakan yang diberikan sehinggu memberikan suasana yang mendukung untuk mampu menstimulus bagi pertumbuhan dan perkembangan ikan nila yang optimal sehingga mempengaruhi tingkat kelulushidupannya. Menurut Rambo et al. (2018), semakin lama waktu pemeliharaan ikan, maka akan semakin baik dalam melakukan adaptasi dengan lingkungan dan menerima pakan yang diberikan. Selain itu, pertumbuhan yang terjadi disetiap minggunya menunjukkan bahwa pakan yang diberikan sudah mampu diserap dan dicerna ikan untuk merangasang pertumbuhan sehingga meningkatkan laju pertumbuhan. 


\section{Kualitas Air}

Kualitas air merupakan salah satu faktor penting yang harus diperhatikan selama penelitian terhadap ikan uji. Parameter kualitas air yang diukur pada penelitian ini adalah suhu, derajat keasaman $(\mathrm{pH})$, dan oksigen terlarut (DO). Data hasil pengukuran kisaran kualitas air selama penelitian dapat dilihat pada Tabel 4.

Tabel 4. Kualitas Air

\begin{tabular}{lcrrrr}
\hline $\begin{array}{l}\text { Parame } \\
\text { ter }\end{array}$ & $\begin{array}{c}\text { Nor } \\
\text { mal }\end{array}$ & \multicolumn{4}{c}{ Perlakuan } \\
\cline { 3 - 6 } & & $\begin{array}{c}\text { Pelet } \\
3 \%\end{array}$ & $\begin{array}{c}\text { Azolla } \\
3 \%\end{array}$ & $\begin{array}{c}\text { Azolla } \\
4 \%\end{array}$ & $\begin{array}{c}\text { Azolla } \\
5 \%\end{array}$ \\
\hline $\begin{array}{l}\text { Suhu } \\
\left({ }^{0} \mathrm{C}\right)\end{array}$ & $25-32$ & 29,1 & 29,0 & 28,8 & 28,1 \\
\hline $\mathrm{pH}$ & $6,5-$ & 6,63 & 6,63 & 6,57 & 6,50 \\
& 9,0 & & & & \\
\hline $\begin{array}{l}\mathrm{DO} \\
(\mathrm{mg} / \mathrm{L})\end{array}$ & $>5$ & 4,55 & 4,57 & 4,70 & 4,82 \\
\hline
\end{tabular}

Berdasarkan Tabel 4. dapat dilihat suhu yang didapat selama penelitian berkisar antara $28,1-29,1^{\circ} \mathrm{C}$. Pada parameter $\mathrm{pH}$, kisaran $\mathrm{pH}$ yang didapatkan selama penelitian 6,57-6,63 dan pada parameter oksigen terlarut (DO), DO yang didapatkan berkisar 4,55 - 4,82 $\mathrm{mg} / \mathrm{L}$.

Suhu yang didapat secara keseluruhan pada masing-masing perlakuan berada pada kisaran yang optimal untuk mendukung pertumbuhan menurut Balai Riset Pemuliaan Ikan (2020). Suhu yang ada pada penelitian merupakan suhu yang ideal, karena jika suhu terlalu panas akan mempengaruhi kelarutan oksigen. Saat suhu meningkat, laju metabolisme ikan meningkat sehingga menyebabkan respirasi ikan meningkat dan kadar oksigen di dalam air dapat menurun secara drastis. Suhu air yang terlalu tinggi atau terlalu rendah dapat menyebabkan ikan tidak dapat tumbuh dan berkembang dengan baik. Syahrizal, et al. (2018), perubahan suhu melebihi $3-4{ }^{\circ} \mathrm{C}$ akan meningkatkan toksisitas kontaminan yang terlarut, menurunkan DO dan meningkatkan kematian pada ikan. Kisaran suhu yang didapatkan selama penelitian dalam kisaran yang stabil antara
28,1-29,1 ${ }^{\circ} \mathrm{C}$ dengan perubahan suhu yang tidak mencapai $3-4{ }^{\circ} \mathrm{C}$. Pada penelitian ini suhu yang didapat merupakan suhu yang ideal karena lokasi penelitian yang ternaung dengan bangunan dan pepohonan sehingga paparan sinar matahari tidak mengenai air secara langsung, sinar matahari mengenai air pada pukul 12.00-16.00 WIB sehingga tidak menyebabkan suhu air berubah secara drastis.

Kisaran $\mathrm{pH}$ yang didapatkan cukup baik dan masih dapat diterima ikan nila serta berada pada nilai batas (Kordi dan M. Ghufran, 2013). pH air memengaruhi tingkat pertumbuhan dan perkembangan tubuh ikan, pada $\mathrm{pH}$ rendah (keasaman tinggi) kandungan oksigen terlarut akan berkurang, sebagai akibatnya konsumsi oksigen menurun, aktivitas pernapasan naik dan selera makan akan berkurang dan sebaliknya terjadi pada suasana basa. Pada penelitian ini kisaran $\mathrm{pH}$ dapat dikatakan cukup baik karena berada pada nilai batas bukan nilai optimal untuk mendukung pertumbuhan dan perkembangan ikan nila, $\mathrm{pH}$ yang didapatkan kurang optimal diduga karena kandungan bahan organik didasar perairan yang mengendap dan kondisi air pada pemeliharaan yang tidak mengalir.

DO yang didapat secara keseluruhan pada masing-masing perlakuan berada pada kisaran yang tidak optimal untuk mendukung pertumbuhan ikan nila menurut Balai Riset Pemuliaan Ikan (2020). Ikan membutuhkan oksigen dalam menghasilkan energi dari pakan yang dikonsumsi untuk menghasilkan aktivitas seperti pergerakan, pertumbuhan, reproduksi dan sebagainya. Oleh karena itu, ketersediaan oksigen bagi ikan menentukan lingkaran aktivitas ikan, rasio konversi pakan, dan laju pertumbuhan bergantung pada oksigen (Kordi et al., 2013).

Pada penelitian ini DO yang didapatkan belum berada pada kisaran DO yang optimal, akan tetapi tidak menjadikan tingkat kelulushidupan ikan menjadi rendah karena ikan nila masih bisa bertahan hidup dengan kisaran Oksigen $3 \mathrm{mg} / \mathrm{L}$. Menurut Youssouf et all.,(2013). ikan nila juga dapat hidup pada perairan dengan kandungan oksigen minim, kurang dari 3 ppm (part per million). Oleh karena itu, ikan ini dapat dipelihara di kolam 
tadah hujan dan air tergenang lain yang minim oksigen, termasuk di kolam terpal. Untuk pertumbuhan optimalnya, ikan nila membutuhkan perairan dengan kandungan oksigen minimal 3 ppm.

Kurang optimalnya DO yang ada diduga karena pada lokasi penelitian yaitu Danau Selais LPPM Universitas Riau merupakan perairan yang menampung semua limbah cair hasil dari aktivitas rumah tangga Universitas riau dan kondisi geografisnya yang berbentuk lembah sehingga menyebabkan aliran air hujan yang turun mengalirkan bahan organik dari sekitaran Danau Selais LPPM Universitas Riau dan mengendap di dasar perariran danau, endapan bahan organik yang menumpuk didasar perairan tersebut mengakibatkan DO menjadi rendah. Menurut Yayuk (2018), limbah domestik yang berasal dari pemukiman biasanya memiliki beberapa sifat utama yaitu mengadung bakteri, bahan organik dan padatan tersuspensi sehingga BOD biasanya tinggi, padatan organik dan anorganik yang mengendap di dasar perairan dan menyebabkan DO rendah. Hasil penelitian Min Chen et al. (2012) pemberian Azolla microphylla dalam pakan menunjukkan hasil yang signifikan serta tidak mempengaruhi kualitas air.

\section{Potensi Hasil Penelitian Sebagai Rancangan Modul Pembelajaran SMA}

Hasil penelitian mengenai pertumbuhan ikan nila (Oreocrhomis niloticus) dengan pemanfaatan pakan Azolla microphylla dapat digunakan sebagai rancangan produk pedagogik atau salah satu bahan ajar berupa modul pada mata pelajaran Biologi materi pertumbuhan dan perkembangan makhluk hidup kelas XII SMA semester Genap. Pembahasan pada setiap tahapan yang telah dilakukan oleh peneliti sebagai berikut.

\section{Tahap Analisis}

Tahapan analisis yang pertama dilihat yaitu pada kurikulum dan materi yang akan dibahas. Analisis kurikulum dilakukan dengan menganalisis silabus yang dikeluarkan oleh Kemendikbud sebagai langkah awal untuk mengetahui apa yang akan dipelajari peserta didik sesuai tuntutan kurikulum 2013 sehingga membantu dalam menentukan masalah dasar pada perancangan modul. Tahap awal ini adapun analisis yang dilakukan meliputi analisis Kompetensi Dasar (KD) dan juga menganalisis silabus Kurikulum 2013 yang dikeluarkan oleh Kemendikbud.

Hasil dari analisis kurikulum dan silabus, peneliti menyimpulkan bahwa kurikulum yang akan dijadikan rancangan modul pada pembelajaran biologi di SMA adalah Kurikulum 2013 dan silabus yang digunakan mengacu pada kemendikbud 2019. Sehingga, kompetensi dasar yang dipilih untuk dijadikan bahan ajar modul adalah KD 3.1 dan 4.1 kelas XII khusus untuk materi pertumbuhan dan perkembangan pada hewan dan faktor yang mempengaruhinya. Hal ini disebabkan pengayaan pada materi tersebut dapat dijadikan pembelajaran berbasis riset yang selanjutnya dipadukan dengan model pembelajaran Problem Based Learning (PBL) dengan pendekatan saintifik dengan tujuan meningkatkan kemampuan analisis dan berfikir kritis peserta didik. Peneliti memfokuskan kepada pertumbuhan ikan nila dengan pemanfaatan pakan Azolla microphylla. Jadi, materi yang dipilih sebagai rancangan modul dengan data hasil penelitian adalah KD 3.1 Menjelaskan pengaruh faktor internal dan faktor eksternal terhadap pertumbuhan dan perkembangan makhluk hidup dan 4.1 Menyusun laporan hasil percobaan tentang pengaruh faktor eksternal terhadap proses pertumbuhan dan perkembangan tanaman. Indikator pengayaan yang dilakukan adalah proses pertumbuhan ikan nila dengan pemanfaatan pakan Azolla microphylla . Data hasil penelitian yang akan digunakan dalam pengayaan modul yaitu data tentang persentase pemberian pakan Azolla microphylla untuk mendukung pertumbuhan ikan nila berdasarkan kurva pertumbuhan dan kualitas air. Data yang digunakan tersebut merupakan hasil penelitian selama 12 minggu pemeliharaan. 


\section{Desain Perangkat Pembelajaran}

Perancangan perangkat pembelajaran meliputi silabus, RPP dan instrumen penilaian. Silabus yang dikembangkan telah disesuaikan dengan surat edaran
Kemendikbud 2019. Silabus dikembangkan dengan 6 kali pertemuan. Adapun rincian materi tersebut dapat dilihat pada table 5 .

Tabel 5. Rincian materi yang dikembangkan dalam Perangkat Pembelajaran.

\begin{tabular}{cl}
\hline Pertemuan & Materi \\
\hline I & $\begin{array}{l}\text { Pertumbuhan dan perkembangan pada } \\
\text { hewan }\end{array}$ \\
II & $\begin{array}{l}\text { Faktor }- \text { faktor yang mempengruh } \\
\text { pertumbuhan dan perkembangan pada } \\
\text { hewan }\end{array}$ \\
III & $\begin{array}{l}\text { Metamorfosis } \\
\text { IV }\end{array}$ \\
& $\begin{array}{l}\text { Pertumbuhan dan perkembangan pada } \\
\text { tumbuhan }\end{array}$ \\
V & $\begin{array}{l}\text { Faktor-faktor yang mempengaruhi } \\
\text { pertumbuhan dan perkembangan pada } \\
\text { tumbuhan }\end{array}$ \\
&
\end{tabular}

\section{Kegiatan}

Diskusi tanya jawab, mengamati gambar, membaca modul pertumbuhan ikan nila (Oreocrhomis niloticus) dengan pemanfaatan pakan Azolla microphylla, mengerjakan LKPD, posttest

Diskusi tanya jawab, mengamati gambar dan video, membaca modul pertumbuhan ikan nila (Oreocrhomis niloticus) dengan pemanfaatan pakan Azolla microphylla, mengerjakan LKPD, posttest

Diskusi tanya jawab, mengamati gambar, membaca modul pertumbuhan ikan nila (Oreocrhomis niloticus) dengan pemanfaatan pakan Azolla microphylla, mengerjakan LKPD, posttest

Diskusi tanya jawab, mengamati gambar, membaca modul pertumbuhan ikan nila (Oreocrhomis niloticus) dengan pemanfaatan pakan Azolla microphylla, mengerjakan LKPD, posttest

Diskusi tanya jawab, mengamati gambar, membaca modul pertumbuhan ikan nila (Oreocrhomis niloticus) mengamati gambar, mendesain rancangan proyek / penelitian posttest
Adapun materi yang dikembangkan pada penelitian ini terdapat pada pertemuan pertama. Rencana Perangkat Pembelajaran (RPP) dirancang untuk satu kali pertemuan 2 X 45 menit. RPP yang dirancang menggunakan model pembelajaran Problem Based Learning (PBL) Penggunaan model ini sesuai dengan kegiatan diskusi kelompok yang akan dilaksanakan oleh siswa. Kegiatan diskusi ini dilaksanakan untuk membahas LKPD dengan refrensi modul Pembelajaran yang telah diberikan oleh guru, sehingga akan menambah pengetahuan siswa seputar pertumbuhan dan perkembangan pada makhluk hidup.

Proses pembelajaran yang dilakukan melalui diskusi kelompok bertujuan untuk meningkatkan kemampuan siswa dalam proses berpikir dan mengemukakan pendapat, sehingga siswa mampu untuk membuat kesimpulan atau menyusun berbagai alternatif pemecahan masalah. Menurut Rosdiana (2017), Problem Based Learning adalah suatu model pembelajaran yang menitik beratkan pada aktifitas siswa dalam belajar dengan tujuan agar siswa dapat memperoleh seluruh atau sebagian pengetahuannya secara mandiri.

Menurut (Nafiah, 2014), langkahlangkah dalam melaksanakan PBL ada 5 fase yaitu (1) mengorientasi siswa pada masalah; (2) mengorganisasi siswa untuk meneliti; (3) membantu investigasi mandiri dan berkelompok; (4) mengembangkan dan menyajikan hasil karya; (5) menganalisis dan mengevaluasi proses pemecahan masalah. RPP yang dirancang menggunakan pendekatan saintifik yang terdiri dari lima langkah yaitu mengamati, menanya, mengumpulkan data, mengasosiasikan, dan 
mengkomunikasikan. Pendekatan scientific dalam hal keilmiahannya sangat tepat untuk diimplementasikan guna peningkatan kualitas peserta didik dalam ranah pengetahuan maupun keterampilan (Yuris, 2020).

\section{Perancangan Modul}

Tahap perancangan modul merupakan tahapan yang dilakukan dalam merancang konsep materi yang berkaitan dengan fakta dan data yang diperoleh dari hasil penelitian. Kemudian merancang indikator dan indikator pencapaian kompetensi yang harus diraih siswa dan merancang butir soal objektif maupun essai sebagai instrumen evaluasi siswa yang mengacu pada indikator pencapaian kompetensi. Indikator yang dicapai yaitu menjelaskan proses pertumbuhan dan perkembangan pada makhluk hidup, mengumpulkan informasi tentang faktor eksternal dan internal yang mempengaruhi pertumbuhan dan perkembangan pada hewan, membandingkan proses perkembangan secara fisika dan kimia, menjelaskan proses terjadinya metamorfosis, Menyusun laporan hasil percobaan tentang faktor eksternal terhadap pertumbuhan dan perkembangan pada tumbuhan. Berikut disajikan format rancangan modul pembelajaran pada Tabel 6 .

Tabel 6. Format Rancangan Modul Pembelajaran

\begin{tabular}{ll}
\hline Modul Pembelajaran \\
\hline 1. Judul/identitas modul \\
2. Kata pengantar \\
3. Daftar isi dan daftar gambar \\
4. Tinjauan Kurikulum \\
5. Panduan Penggunaan Modul \\
6. Peta Konsep \\
7. Pendahuluan \\
8. Penjabaran Materi Pokok \\
9. Evaluasi (Tes Kognitif, Tes Psikomotor, \\
Penilaian Sikap ) \\
10. Kunci Jawaban \\
11. Daftar pustaka
\end{tabular}

\section{KESIMPULAN}

Pemberian pakan Azolla microphylla memengaruhi pertumbuhan ikan nila (Oreochromis niloticus). Perlakuan P3 (pemberian 5\% Azolla microphylla dari biomassa ikan) merupakan dosis terbaik dalam meningkatkan pertumbuhan ikan nila. Menghasilkan pertumbuhan panjang mutlak $4,24 \mathrm{~cm}$, bobot mutlak $11,72 \mathrm{~g}$, pertumbuhan nisbi $4,68 \%$, laju pertumbuhan spesifik $0,021 \%$ dan tingkat kelulushidupan 99,4\% . Perlakuan P3 menghasilkan pertumbuhan yang selisihnya sangat jauh lebih rendah dengan perlakuan P0 (kontrol). Dari hasil penelitian yang telah diperoleh dapat dikembangkan sebuah modul pembelajaran Biologi pada materi pertumbuhan dan perkembangan makhluk hidup.

\section{DAFTAR PUSTAKA}

Arif Rahman Hakim, Koko Kurniawan, dan Zaenal Arifin Siregar. 2019. Pengaruh Penggantian Tepung Ikan Dengan Tepung Larva Hermetia Illucens dan Azolla Sp. Terhadap Kualitas Pakan Ikan Terapung. Jurnal Riset Akuakultur. 14 (2) : 77 85.

Akito Ochiai, Shunsuke Koshio And Emile D. Fiogbe. 2017. Effect of total replacement of fishmeal by earthworm and Azolla filiculoidesmeals in the diets of Nile tilapia Oreochromis niloticus (Linnaeus, 1758) reared in concrete tanks. Indian Journal Fish. 64(1): 31-36.

Dita Widiyanti Sawitri. 2014. pengembangan modul keanekaragaman hayati berbasis pendekatan saintifik untuk siswa kelas x sma. Berkala Ilmiah Pendidikan Biologi. 3(3) : 410-415.

Kementerian Kelautan dan Perikanan [KKP]. (2018). Laporan Tahunan Tahun 2017. Kementerian Kelautan dan 
Perikanan RI. 68 hlm; ISBN: 978602-52195-0-4.

Kordi K. dan Ghufran M. H. 2013. Budidaya Ikan Konsumsi Di Air Tawar. Lily Publisher. Yogyakarta.

Min Chen, Sufang Deng, Youquan Yang, Yibing Huang and Chongchu Liu. 2012. Efficacy of oxygen-supplying capacity ofAzollain a controlledlife support system. International Journal of Advanced Research. 49(5): 487-492.

Prastowo A. 2015. Panduan Kreatif Membuat Bahan Ajar Inovatif. DIVA Press. Yogyakarta.

Samuel Sitorus. 2019. Pemanfaatan Tepung Limbah Sayur Sawi dan Kubis yang Difermentasi Dengan Rhyzhopus sp. dalam Pakan Benih Ikan Gurami (Osphronemus gouramy). Jurnal Online Mahasiswa Bidang Perikanan dan Ilmu Kelautan 6: 115

S.B. Katole1, Shweta R. Lende and S.S. Patil. 2017. A Review on Potential Livestock Feed: Azolla. Livestock Research International Journal. 5(1) : 1-9.

S. K. Hundare, D. I. Pathan and A. B. Ranadive. 2018. Use of Fermented Azolla in Diet of Tilapia Fry (Oreochromis niloticus). International Journal of Bioresource and Stress Management. 9(6):702-706.

Yaki Akawo Angwal, Midat Caroline Yunana, and Bawa Saratu. 2020. Development and Evaluation of Innovative Instructional Module for Teaching and Learning of Biology in Senior Secondary Schools. Journal of Library, Science Educationand Learning Technology. 2(1) : 1-13.
Youssouf Abou, Martin P. Aina, Emile D. Fiogbe, Jean-Claude Micha. 2013. Growth and fatty acid composition of Nile tilapia Oreochromis niloticus L. fed Azolla-diets, in tanks and in earthen ponds: A comparative study. Natural Science. 5(1): 77-83.

Yustiati, Yayat Dhahiyat, Rita Rostika. 2018. Pengaruh Penambahan Tepung Biji Turi Hasil Fermentasi pada Pakan Komersial Terhadap Pertumbuhan dan Kelangsungan Hidup Ikan Nila (Oreochromis niloticus). Jurnal Perikanan dan Kelautan. 9 (1): $95-$ 103. 